\title{
Deference to State Courts in Federal Interpleader Actions
}

The salutary purpose of the Federal Interpleader Act $^{1}$ is to avoid multiple litigation and the consequent possibility of inconsistent results. ${ }^{2}$ It would surprise a layman to learn ${ }^{3}$ that, while the statutory remedy continues to be available to litigants in the federal courts, parallel suits in state courts, involving the same parties and issues, often proceed simultaneously. 4 This situation is anomalous in light of the policy of the Act of avoiding multiple litigation. It results in part from the confusion engendered by recent decisions of the Supreme Court that have attempted to delineate the scope of judicial discretion to enter a stay in a suit properly before the federal court. ${ }^{5}$ Another cause is the unwillingness to enjoin proceedings in state courts, even though such injunctions are expressly authorized by the Interpleader Act. ${ }^{\circ}$

This comment argues that, in the situation described above, it is a sound exercise of discretion for a federal judge to stay or dismiss the federal proceeding in deference to the parallel state suit. Such a result is particularly desirable in view of the increasingly unmanageable workload of the federal courts. ${ }^{7}$

128 U.S.C. \$§ 1335, 1397, 2361 (1976).

* See generally Texas v. Florida, 306 U.S. 398, 412 (1939); Zellen v. Second New Haven Bank, 454 F. Supp. 1359, 1365-66 (D. Conn. 1978); 2 W. Barron \& A. Holtzorf, Federal Practice and Procedure § 551, at 227 (rev. ed. 1961); Hazard \& Moskovitz, An Historical and Critical Analysis of Interpleader, 52 Caurf. L. Rev. 706, 751 (1964).

s T. B. Harms Co. v. Eliscu, 339 F.2d 823, 824 (2d Cir. 1964) (Friendly, J.).

- E.g., Boston Old Colony Ins. Co. v. Balbin, 591 F.2d 1040 (5th Cir. 1979); Ungar v. Mandell, 471 F.2d 1163 (2d Cir. 1972).

s E.g., Will v. Calvert Fire Ins. Co., 437 U.S. 655 (1978). Professor Currie deems the case "inconclusive." D. Currie, Frderal Courts 99 (2d ed. Supp. 1978); accord, 24 VILL. L. REv. 815 (1979). The subsequent history of the Will case offers ample evidence of the confusion generated by the Court's opinions. See Calvert Fire Ins. Co. v. Will, 586 F.2d 12 (7th Cir. 1978); Calvert Fire Ins. Co. v. American Mut. Reins. Co., 459 F. Supp. 859 (N.D. Ill. 1978), aff'd, 600 F.2d 1228 (7th Cir. 1979).

- 28 U.S.C. $\S 2361$ (1976).

7 See, e.g., Klein v. Walston \& Co., 432 F.2d 936, 937 (2d Cir. 1970); Sheran \& Isaacman, State Cases Belong in State Courts, 12 Creighton L. Rev. 1 (1970). 


\section{The Federal Interpleader Act}

The Federal Interpleader Act substantially resembles its historical antecedent, the equitable procedural device known as a bill of interpleader. ${ }^{8}$ The policy underlying the development and formulation of the remedy is the avoidance of a multiplicity of suits over a single res, fund, or claim, and the consequent possibility of inconsistent results. ${ }^{\circ}$

The Act was passed in response to the 1916 decision of the Supreme Court in New York Life Insurance Co. v. Dunlevy, ${ }^{10}$ which affirmed a judgment requiring the insurance company to pay the full cash surrender value of a life insurance policy to the assignee of the policyholder. To the chagrin of New York Life, however, a prior state suit to which the assignee could not be joined had resulted in a judgment for the assignor on the same policy. This injustice made it plain that, because of limitations on state service of process, together with the fact that adverse claimants to a fund often do not reside in the same jurisdiction, ${ }^{11}$ state courts were incapable of affording full relief in those cases in which a stakeholder was faced with inconsistent claims pursued by claimants of diverse citizenship.

Responding with considerable alacrity to Dunlevy, Congress enacted the Federal Interpleader Act a mere eight months after the case was decided.12 The scope of the 1917 Act shows that its formulation and passage directly resulted from the imposition of double liability on the New York Life Insurance Company. The ability to file original bills of interpleader was restricted to "any insurance company or fraternal or beneficiary society."1s Because the Dunlevy situation arises only when a state court is precluded, by reason of diverse citizenship, from compelling joinder of all claimants, the Act included, as a necessary incident, a provision for nationwide service of process. ${ }^{14}$ The principal function of the 1917 Act thus was jurisdictional: it expanded the jurisdiction of the federal courts to allow relief by interpleader, whenever diversity among the claimants rendered full relief in a state court problematic.

- See 4 J. Pomerox, A Treatise on Equity Jurisprudence § 1320 (5th ed. 1941).

- Id.

10241 U.S. 518 (1916).

1 See generally S. Rep. No. 660, 64th Cong., 1st Sess. 1 (1916).

12 Act of Feb. 22, 1917, ch. 113, 39 Stat. 929 (repealed 1926). Dunlevy was decided June 5, 1916; the statute was approved Feb. 22, 1917.

is Id.

14 Id. 
Although passage of the Act immediately alleviated the concern caused by Dunlevy, unresolved questions remained. The utility of the equitable bill of interpleader had been severely impaired by four judicially created prerequisites to relief. ${ }^{15}$ Given their classic formulation by Pomeroy, ${ }^{16}$ these "requirements" were applied mechanically so as to deny interpleader in some cases where a stakeholder was faced with the possibility of multiple or inconsistent liabilities. ${ }^{17}$

Having concluded that it was of primary importance to rid the statutory remedy of "antiquarian and metaphysical incrustations,"18 Professor Chafee sought to ensure that the Act was not interpreted as embodying Pomeroy's four requirements. As commentator, draftsman, and advisor, he had a profound effect on Congress. ${ }^{19}$ That his advice was sought and closely followed each time the Act was revised ${ }^{20}$ is widely recognized. ${ }^{21}$ Indeed, Congress

18 Chafee, Modernizing Interpleader, 30 YaLe L.J. 814, $821-22$ (1921).

${ }^{16} 4$ J. Pomeroy, supra note 8 , $\$$ 1322-1326. The four prerequisites were (1) that the same thing, debt, or duty be claimed by both or all parties from whom relief was sought; (2) all adverse titles must be dependent on or derived from a common source; (3) the plaintiff in interpleader must not have any interest in the subject matter of the suit; and (4) the plaintiff must be merely a stakeholder, indifferent to the claimants.

17 See generally Chafee, supra note 15.

18 Id. at 822.

19 Professor Chafee wrote a series of articles on federal interpleader: Modernizing Interpleader, 30 YALE L.J. 814 (1921); Interstate Interpleader, 33 YALE L.J. 685 (1924); Interpleader in the United States Courts (pts. 1-2), 41 YALE L.J. 1134, 42 YaLE L.J. 41 (1932); The Federal Interpleader Act of 1936 (pts. 1-2), 45 YALE L.J. 963, 1161 (1936); Federal Interpleader Since the Act of 1936, 49 YALE L.J. 377 (1940). Professor Chafee's influence in this area also derived from his role as advisor to the section on insurance law of the American Bar Association; indeed, his report to that body in 1933 contained a proposed draft for the statutory revision that was substantially the same as the one approved by Congress in 1936. Cf. Seeburger, The Federal Long-Arm: The Uses of Diversity, or T'ain't So, McGee, 10 IND. L. REv. 480, 496 \& n.63 (1977) (Chafee drafted the 1936 amendments).

${ }^{20}$ Act of Feb. 22, 1917, ch. 113, 39 Stat. 929 (repealed 1926); Act of Feb. 25, 1925, ch. 317, 43 Stat. 976 (repealed 1926); Act of May 8, 1926, ch. 273, 44 Stat. 416 (repealed 1936); S. Con. Res. No. 16, 69th Cong., 1st Sess., 44 Stat. 1979 (1926); Act of Jan. 20, 1936, ch. 13, 49 Stat. 1096 (current version at 28 U.S.C. $\$ \$ 1335,1397,2361$ (1976)). The Act was "amended" again in 1948 as part of the revision of the Judicial Code, Act of June 25, 1948, ch. 646, 62 Stat. 931 (current version at 28 U.S.C. $§ \S 1-2906$ (1976, Supp. I 1977 \& Supp. II 1978). The accompanying Senate Report stated that "[g]reat care has been exercised to make no changes in existing law which would not meet with substantially unanimous approval." S. Rap. No. 1559, 80th Cong., 2d Sess. 2 (1948). Since the 1948 changes in the Interpleader Act were cosmetic, the 1936 revision may be regarded as the final substantive change in the Act.

${ }^{21}$ See, e.g., 2 W. BARRon \& A. Holtzorf, supra note 2, § 551, at 226. 
expressly acknowledged its reliance on his work. ${ }^{22}$ Federal interpleader was given its current formulation when the Judicial Code was revised in 1948.23 The Act now represents a minor triumph of the legal imagination: it is a sensible, pragmatic response to the problems of double liability and multiple suits. ${ }^{24}$

\section{The Absolute Right Doctrine and the Avoidance of Duplicative Litigation}

The law regarding the propriety of a federal court stay or dismissal in deference to parallel state court litigation is undergoing a metamorphosis. ${ }^{25}$ Whether this process will be completed is still in doubt, however, because the few Supreme Court decisions dealing with the issue not only are marked by a lack of clarity, ${ }^{26}$ but for the most part have been rendered by a closely divided Court with a vigorous dissent. ${ }^{27}$ While in the past a plaintiff who had properly invoked federal jurisdiction was regarded as having an "absolute right" to have the lawsuit heard in the forum ${ }^{28}$ recent decisions suggest that, at least in certain classes of cases, it is within the discretion of the district court to stay or dismiss the suit in deference to pending state court proceedings. ${ }^{2 \theta}$

22 S. REp. No. 1417, 73d Cong., 2d Sess. 1 (1934).

${ }^{23}$ Act of June 25, 1948, ch. 646, 62 Stat. 931 (current version at 28 U.S.C. $\$ \S 1-2906$ (1976, Supp. I 1977 \& Supp. II 1978)).

26 "Interpleader possesses on first acquaintance an attractiveness which is not exceeded by any other remedy known to the law. 'The mere statement of the principle,' declared Sir James Willes, 'shows its justice." " Chafee, supra note 15, at 814 (footnote omitted) (quoting Evans v. Wright, 13 W.R. 468 (Ch. 1865)).

25 Compare Louisiana Power \& Light Co. v. City of Thibodaux, 360 U.S. 25 (1959) with Meredith v. City of Winter Haven, 320 U.S. 228 (1943).

${ }^{26}$ See, e.g., Will v. Calvert Fire Ins. Co., 437 U.S. 655 (1978); Colorado River Water Conservation Dist. v. United States, 424 U.S. 800, 817-20 (1976). With respect to Colorado River, Professor Currie notes that "I have viewed Colorado River as expanding the Court's willingness to allow federal courts to refuse to hear cases within their jurisdiction. . . . An interesting comment, however, argues that Colorado River actually narrowed the category of dismissals or stays in deference to state court proceedings." D. CuRRIE, supra note 5, at 98 (citing Comment, Federal Court Stays and Dismissals in Deference to Parallel State Court Proceedings: The Impact of Colorado River, 44 U. CHI. L. REv. 641 (1977)). Two treatises agree that the matter is unsettled. IA J. Moore, Fedrral Practice II 0.203[4], at 2141 (2d ed. 1979); C. WRIGHT, HANDBOOK OF THE LAW OF FedRRAL CourTs § 52, at 228 (3d ed. 1976).

${ }_{27}$ See, e.g., Will v. Calvert Fire Ins. Co., 437 U.S. 655 (1978). Three Justices joined in the opinion of Justice Rehnquist; Justice Blackmun concurred in the judgment; and the Chief Justice and two others joined in the dissenting opinion of Justice Brennan.

28 See text and notes at notes 30-42 infra.

29 See text and notes at notes 43-65 infra. 


\section{A. The Absolute Right Doctrine-and Exceptions}

The traditional view of the absolute right doctrine derives from the dictum of Chief Justice Marshall:

It is most true, that this court will not take jurisdiction if it should not: but it is equally true that it must take jurisdiction, if it should. . . . We have no more right to decline the exercise of jurisdiction which is given, than to usurp that which is not given. The one or the other would be treason to the constitution. ${ }^{30}$

The ineluctable result of this reasoning is that, once having properly invoked federal jurisdiction, the plaintiff has an absolute right to have the cause decided by that court. The federal courts therefore have a correlative duty to exercise the jurisdiction conferred upon them. The dispositive factor is the congressional determination, as manifested in the relevant jurisdictional statute, that a given class of plaintiffs is to be allowed access to the federal courts. This reasoning, based on the general constitutional allocation of governmental functions, ${ }^{31}$ does not distinguish among the numerous specific grants of federal jurisdiction.

There is, however, no such thing as an "absolute" right. Accordingly, it is not surprising that the right to litigate in federal courts has been qualified by several categories of exceptions.

1. The Exception of Duplicative In Rem Suits. It was established early ${ }^{32}$ that the distinction between suits that are in rem and those that are in personam necessitated a qualification of the absolute right doctrine. When a suit is in rem, the first court to gain jurisdiction over the res is said to have exclusive jurisdiction; no other court, whether federal or state, can then adjudicate the proper disposition of that res. ${ }^{33}$ Thus, only if parallel suits are in personam is there danger of duplicative litigation.

Interpleader suits can be either in rem or in personam, ${ }^{34} \mathrm{de}-$

so Cohens v. Virginia, 19 U.S. (6 Wheat.) 264, 404 (1821). One commentator notes that the theory represented by these dicta has "gained respectability through repetition." Note, Power to Stay Federal Proceedings Pending Termination of Concurrent State Litigation, 59 YALE L.J. 978, 980 (1950).

sI U.S. CoNST. art. III, §§ $1 \& 2$.

32 See Toucey v. New York Life Ins. Co., 314 U.S. 118, 134-36 (1941). The in rem exception derives from Hagan v. Lucas, 35 U.S. (10 Pet.) 400 (1836).

ss See, e.g., Kline v. Burke Constr. Co., 260 U.S. 226, 230 (1922).

s* See, e.g., Metropolitan Life Ins. Co. v. Dumpson, 194 F. Supp. 9 (S.D.N.Y. 1961) (interpleader in personam); Flanagan v. Marvel, 94 F. Supp. 145 (D. Minn. 1950) (inter- 
pending on whether the stakeholder is faced with inconsistent claims to property in possession, or to a chose in action. Several courts have reasoned that because federal interpleader requires that the stakeholder deposit the money or property in controversy "into the registry of the court,"3s therefore all interpleader suits are in rem..$^{36}$ In any event, when a state court has jurisdiction over tangible property that is the subject of controversy, a federal court will not entertain a suit seeking disposition of the same property, despite the supposed absolute right of the party invoking federal jurisdiction.

When a federal court dismisses a suit because a state court has prior jurisdiction over the res, it could be argued that jurisdiction was lacking entirely. In the alternative, such a dismissal can be viewed as a refusal to exercise a jurisdiction that has been properly invoked. In either case, the accepted treatment of such suits indicates that, under proper circumstances, the absolute right doctrine may yield in order to facilitate rational judicial administration.

2. Abstention as an Exception to the Absolute Right Doctrine. In accord with principles of comity and federalism, the Supreme Court has delineated certain classes of cases in which, despite the absolute right doctrine, the federal courts may abstain from the exercise of a properly invoked jurisdiction.

First, abstention may be appropriate when a case presents a federal constitutional issue that might be mooted or presented in a different posture by a prior state court construction of an applicable but unclear state law. ${ }^{37}$ This category is commonly referred to

pleader in rem), appeal dismissed, 189 F.2d 966 (8th Cir. 1951). But see Hanna v. Stedman, 230 N.Y. 326, 335, 130 N.E. 566, 569 (1921) (interpleader never in rem). See generally Annot., 17 A.L.R. Fed. 447 (1973). For the classic statement of the doctrine that when a state court has taken jurisdiction of a res, a federal court must decline jurisdiction, see Princess Lida v. Thompson, 305 U.S. 456, 465-67 (1939) (citing Pennsylvania Gen. Cas. Co. v. Pennsylvania, 294 U.S. 189, 195 (1935)). In this situation the state court may enjoin further proceedings in the federal court, 305 U.S. at 467 , though the rule generally is contrary. Donovan v. City of Dallas, 377 U.S. 408 (1964).

ss 28 U.S.C. $\S 1335(a)(2)(1976)$.

${ }^{28}$ E.g., Cramer v. Phoenix Mut. Life Ins. Co., 91 F.2d 141, 145 (8th Cir.) (where proceeds of insurance policies paid into court, case resembles a suit in rem), cert. denied, 302 U.S. 739 (1937); Glasser v. Rogers, 59 F. Supp. 986, 988 (S.D.N.Y.), aff'd sub nom. Glasser v. Wessel, 152 F.2d 428 (2d Cir. 1945) (trust located in state as basis for state in rem jurisdiction), cert. denied, 328 U.S. 839 (1946).

s7 E.g., County of Allegheny v. Frank Mashuda Co., 360 U.S. 185, 189 (1959); Railroad Comm'n v. Pullman Co., 312 U.S. 496 (1941). See also Colorado River Water Conservation Dist. v. United States, 424 U.S. 800, 814 (1976). 
as Pullman abstention. ${ }^{38}$ Second, a federal court may decide that abstention is appropriate if "the exercise of federal review in [this] case and in similar cases would be disruptive of state efforts to establish a coherent policy with respect to a matter of substantial public concern." "ss The third category of abstention extends to those cases in which the parties have an adequate remedy at law in a pending state court proceeding to which the state is a party, or at least in which the state has an interest analogous to its interest in the prosecution of criminal cases. ${ }^{40}$

It should be noted that courts and commentators are not in substantial agreement concerning the appropriate terminology. ${ }^{41} \mathrm{It}$ is adequate for purposes of this comment to use the term "abstention" in a generic sense to describe the situations just mentioned in which a federal court refuses to hear a case properly before it. This usage is consistent with that of the Supreme Court in Colorado River Water Conservation District v. United States. ${ }^{42}$

\section{B. The New Approach: Stays or Dismissals for Reasons of Wise Judicial Administration}

The previous section illustrates the traditional approach when a federal court is asked to stay its hand despite the existence of jurisdiction over the suit: the case will proceed to judgment unless it falls within one of the exceptions to the absolute right doctrine. The following discussion will demonstrate that a further inquiry by the court is permissible even when the federal suit is within neither the in rem justification for the avoidance of jurisdiction, nor any one of the abstention categories. Thus, when reasons of

ss The designation derives from the seminal case, Railroad Comm'n v. Pullman Co., 312 U.S. 496 (1941).

so Colorado River Water Conservation Dist. v. United States, 424 U.S. 800, 814 (1976). This category derives from Burford v. Sun Oil Co., 319 U.S. 315 (1943), and Alabama Pub. Serv. Comm'n v. Southern Ry., 341 U.S. 341 (1951). Suits of this sort generally involve challenges to state regulatory programs. See generally Comment, Abstention by Federal Courts in Suits Challenging State Administrative Decisions: The Scope of the Burford Doctrine, 46 U. CHI. L. REv. 971 (1979). See also Kaiser Steel Corp. v. W.S. Ranch Co., 391 U.S. 593 (1968).

to E.g., Younger v. Harris, 401 U.S. 37 (1971).

1 See C. Wright, supra note $26, \S 52$, at 218 (four categories of abstention); Note, Federal Intervention in Ongoing State Proceedings: Expansion of an Abstention Doctrine, 25 Drake L. Rev. 482, 483 (1975) (six categories); Comment, Post-Younger Excesses in the Doctrine of Equitable Restraint: A Critical Analysis, 1976 Duke L.J. 523, 526 \& n.15 (differentiating abstention from equitable restraint); 8 CuM. L. REv. 589, 590 n.9 (1977) (distinguishing between abstention and "nonintervention").

42424 U.S. 800 (1976). 
wise judicial administration outweigh the obligation of the federal courts to decide cases properly before them, cases are legitimately stayed or dismissed. Such an inquiry requires a balancing of relevant factors, an operation analytically distinct from that involved when the issue is the propriety of abstention, which requires only a determination that the relevant characteristics are present.

Here again there is a terminological difficulty. Some commentators think that this category of cases constitutes a fourth branch $^{43}$ of the abstention doctrine. For purposes of simplicity, the term "abstention" will be used here with the understanding that the generic sense is meant. It should be borne in mind, however, that the analysis required with respect to this fourth type of "abstention" is fundamentally different from that employed when considering whether abstention is appropriate for any of the reasons previously discussed.

1. The Pedigree of the Balancing Approach. The origins of abstention for reasons of wise judicial administration lie in three cases widely separated in both time and subject matter. Analysis of the cases, however, yields a common denominator that serves as the theoretical underpinning of this fourth category of abstention.

In the first case, Langnes $v$. Green, ${ }^{44}$ a personal injury claim had been filed in state court against a shipowner, whose response was to petition a federal court for limitation of liability. Although the federal court clearly had jurisdiction ${ }^{45}$ and the state court could not determine the right to limit liability, the Supreme Court held that the federal court should have stayed its hand:

[T] the rights of both parties. . . . [T] he district court . . . should [have permitted] the cause to proceed in the state court, retaining, as a matter of precaution, the petition for a limitation of liability to be dealt with in the possible but . . . unlikely event that the right of petitioner to a limited liability might be brought into question in the state court . . . ${ }^{18}$

The Court thus balanced the right of the shipowner to sue in federal court against the benefits to be derived from allowing the state suit to proceed, and found the scales tipped in favor of the latter.

13 C. WRIGHT, supra note 26 , at 218.

4282 U.S. 531 (1931).

1546 U.S.C. § 185 (1976).

16 282 U.S. at $541-42$. 
This is arguably a special case because of the clause in the statute "saving to suitors" all common law remedies, thus allowing jury trials in state court, whereas federal admiralty jurisdiction does not provide for a jury. Nevertheless, the case is important for its demonstration of the Court's willingness to consider, on a pragmatic basis, which forum could best provide for the interests of the parties.

In Canada Malting Co. v. Paterson Steamships, Ltd., ${ }^{48}$ a suit in admiralty between foreigners, the Supreme Court expressly rejected Chief Justice Marshall's dictum in Cohens, ${ }^{49}$ and said that it was within the discretion of the district court to refuse to retain jurisdiction: "Obviously, the proposition that a court having jurisdiction must exercise it, is not universally true . . . . Courts of equity and of law ... ocassionally [sic] decline, in the interest of justice, to exercise jurisdiction ....".\$o

The Court found that the "interest of justice" permitted the district court to relegate the parties to their home forum. Such a result was acceptable because it took into account both judicial economy, in that the court could thereby avoid deciding difficult questions of foreign law, and convenience to the litigants, who, it was thought, could pursue the litigation more expeditiously at home. ${ }^{51}$ Further proof of the Court's approval of balancing such factors is its citation to an article on forum non conveniens that favored just such a balancing. ${ }^{\mathbf{2}}$

In Brillhart v. Excess Insurance Co. of America, ${ }^{5 s}$ the Supreme Court held that a suit brought under the Declaratory Judgments Act $^{54}$ could properly be dismissed when parallel litigation was pending in a state court. "Ordinarily it would be uneconomical as well as vexatious for a federal court to proceed in a declaratory judgment suit when another suit is pending in a state court presenting the same issues, not governed by federal law, between the same parties."ss Clearly, then, if it would be "economical" for

428 U.S.C. \& 1333(1) (1976).

18285 U.S. 413 (1932).

40 See text at note 30 supra.

so 285 U.S. at $422-23$ (dictum).

s1 Id. at $423-24$.

${ }^{32}$ Id. at 423 n.6 (citing Blair, The Doctrine of Forum Non Conveniens in Anglo-American Law, 29 CoLuM. L. REv. 1 (1929)).

ss 316 U.S. 491 (1942).

s4 28 U.S.C. \$§ 2201-2202 (1976).

ss 316 U.S. at 495. 
the district court to proceed, it should do so; the Court did not hold that declaratory relief was never available if the same parties were involved in litigation pending before a state court. In order to aid federal courts in this balancing of economies, the Court explained that it would be proper to inquire into the scope of the pending state suit, the defenses available, whether the claims of all parties could be disposed of, and whether necessary parties had been or could be joined..$^{\text {s }}$

Langnes, as noted, arguably is special because of the policy underlying the savings clause in the statute conferring admiralty jurisdiction. ${ }^{57}$ The same is true of Canada Malting because the litigation was entirely between foreigners, and of Brillhart because of the peculiarly discretionary nature of declaratory relief. Nevertheless, taken together, these cases demonstrate a willingness to accept the propriety of a balancing of equities in order to avoid the waste inherent in duplicative litigation. The Fifth Circuit agrees with this conclusion: "Brillhart and cases decided after it . . . have made manifest a policy against dual litigation which . . . has given rise to a discretionary power in the federal courts to stay proceedings in equity suits in deference to a parallel state action."88

2. Express Approval of Balancing. The balancing approach implicit in Langnes, Canada Malting, and Brillhart was expressly approved in Colorado River Water Conservation District $v$. United States. ${ }^{60}$ There the government brought a water rights suit in the federal district court, and subsequently was joined in a similar suit in state court. The Supreme Court affirmed the district court's dismissal of the federal suit.

Speaking for the Court, Justice Brennan reviewed the first three categories of abstention. Concluding that none was relevant to the case at bar, he nevertheless found the dismissal proper: "[T]here are principles unrelated to considerations of proper constitutional adjudication and regard for federal-state relations which govern in situations involving the contemporaneous exercise of concurrent jurisdictions . . . . These principles rest on considerations of ' $[w]$ ise judicial administration, giving regard to conservation of judicial resources and comprehensive disposition of

ss Id.

57 See text and note at note 47 supra.

68 PPG Indus., Inc. v. Continental Oil Co., 478 F.2d 674, 679 (5th Cir. 1973) (footnote omitted).

bo 424 U.S. 800, 818-19 (1976); see Comment, supra note 26, at 659-64. 


\section{litigation." "60}

In affirming the dismissal in this case, the Court relied heavily on the policy it found to underlie the McCarran amendment, ${ }^{61}$ by which the United States consents to suit in cases involving water rights: "The clear federal policy evinced by that legislation is the avoidance of piecemeal adjudication of water rights . . . ."62 While such a policy is implicit in the McCarran amendment, the avoidance of multiple litigation and the consequent possibility of inconsistent results is the sole policy underlying the Federal Interpleader Act. Thus if the policy found by the Court to underlie the McCarran amendment justifies abstention for reasons of wise judicial administration, then, a fortiori, such abstention should be permissible in interpleader suits as well.

The Court in Colorado River also cited Brillhart as illustrative of the general propriety of avoiding piecemeal litigation, ${ }^{63}$ and mentioned two other factors to be weighed in assessing whether to dismiss a suit: the inconvenience of the federal forum, and the order in which jurisdiction was obtained by the concurrent forums. ${ }^{\text {s4 }}$ The Court concluded that "[n]o one factor is necessarily determinative; a carefully considered judgment taking into account both the obligation to exercise jurisdiction and the combination of factors counselling against that exercise is required."6s This language establishes beyond dispute that Colorado River legitimizes a balancing approach to abstention for reasons of wise judicial administration.

\section{The Content of the Balancing Test}

Federal court deference to duplicative state court litigation assumes, of course, that the parallel state suit is adequate to protect the interests of the litigants. Thus the threshold inquiry concerns the degree of protection afforded the parties should they be relegated to the state forum exercising concurrent jurisdiction: is there an "adequate" remedy "at law"? A finding that the pending state proceedings are in some way inadequate to protect a stakeholder

so 424 U.S. at 817 (quoting Kerotest Mfg. Co. v. C-O-Two Fire Equip. Co., 342 U.S. 180, 183 (1952)).

4143 U.S.C. $\$ 666$ (1976).

${ }^{62} 424$ U.S. at 819 .

4 Id. at 818.

st Id.

${ }^{6 s}$ Id. at 818-19. See also Will v. Calvert Fire Ins. Co., 437 U.S. 655, 663-67 (1978). 
faced with inconsistent claims would of necessity preclude a stay or dismissal in deference to those proceedings; were it otherwise, the Supreme Court would soon be deciding Dunlevy all over again. Once this threshold is crossed-that is, once the protection afforded the parties by the state suit is found to be adequate-the balancing test will determine the propriety of a stay or dismissal of the federal interpleader suit in deference to those proceedings.

On the one hand there is the "virtually unflagging obligation $^{\prime \prime 86}$ of the federal courts to exercise the jurisdiction conferred upon them; on the other there may be a congeries of factors counselling against such exercise. When the latter factors outweigh the obligation to decide the suit, the district court may stay or dismiss it. Giving precise content to both halves of this equation is a simple matter. First, the "virtually unflagging" duty can be defined in terms of the degree of permissiveness or compulsion inherent in the grant of interpleader jurisdiction, as manifested in the nature of the remedy and the legislative history. Second, considerations of wise judicial administration require a finding only as to which suit will more efficiently and completely dispose of the litigation.

\section{A. The Threshold Inquiry: Is There an Adequate State Remedy?}

Virtually all federal courts that have stayed their own proceedings in deference to parallel state litigation have required some showing, or have at least asserted, that the pending state proceedings are adequate to protect the rights of all the parties. ${ }^{87}$ Conversely, deference to state proceedings is found to be inappropriate if those proceedings are for any reason inadequate to render a full adjudication of the matter in controversy. ${ }^{68}$ In affirming the dismissal in Brillhart, the Supreme Court gave some guidance as to the proper scope of this inquiry. A decision as to whether the controversy can better be settled in the pending state suit would

ce 424 U.S. at 817.

o7 E.g., Home Indem. Co. v. Moore, 499 F.2d 1202, 1205 (8th Cir. 1974); Koehring Co. v. Hyde Constr. Co., 424 F.2d 1200, 1202-04 (7th Cir. 1970); B.J. Van Ingen \& Co. v. Connolly, 225 F.2d 740, 743 (3d Cir. 1955); Zellen v. Second New Haven Bank, 454 F. Supp. 1359, 1364 (D. Conn. 1978); Equitable Life Assurance Soc'y v. Cooper, 328 F. Supp. 1126, 1127 (W.D. Okla. 1971); Agricultural Ins. Co. v. Lido of Worcester, Inc., 63 F. Supp. 799, 802 (D. Mass. 1945); Mutual Life Ins. Co. v. Egeline, 30 F. Supp. 738, 741 (N.D. Cal. 1939).

-s E.g., Austin v. Texas-Ohio Gas Co., 218 F.2d 739, 746 (5th Cir. 1955); National Fire Ins. Co. v. Sanders, 38 F.2d 212, 214-15 (5th Cir. 1930); Kulovitz v. Illinois High School Ass'n, 462 F. Supp. 875, 877 \& n.2 (N.D. Ill. 1978); Commonwealth Edison Co. v. Gulf Oil Corp., 400 F. Supp. 888, 889-90 (N.D. Ill. 1975), aff'd, 541 F.2d 1263 (7th Cir. 1976); Jefferson Std. Life Ins. Co. v. Smith, 161 F. Supp. 679, 680-81 (E.D.S.C. 1956). 
properly entail an "inquiry into the scope of the pending state court proceeding and the nature of the defenses open there," and "[t]he federal court may have to consider whether the claims of all parties in interest can satisfactorily be adjudicated in that proceeding, whether necessary parties have been joined, [or] whether such parties are amenable to process in that proceeding . . . ."168

At least one court has gone so far as to place the burden of showing the inadequacy of the state proceeding on the party opposing the stay. ${ }^{70}$ This hardly seems appropriate in view of the "virtually unflagging" obligation of the federal courts to decide cases properly before them; in interpleader suits, however, this obligation is not so strong as it is when the action is one brought under the general diversity statute. Thus it would seem fair, at least in suits brought under the Federal Interpleader Act, to place the burden of showing inadequacy of the state court proceedings on the party responsible for bringing the duplicative federal suit. ${ }^{71}$

It is not difficult to determine the adequacy of relief afforded the parties when the state court has already rendered judgment; ${ }^{72}$ this is true if the decision has been announced, even though steps such as entry of the decree remain to be taken. ${ }^{73}$ In this situation it is plain that the purpose of the federal statute has been accomplished without the necessity of its application. ${ }^{74}$

This is also true when all necessary parties are already before the state court. The federal interpleader statute was enacted in response to the situation presented by the Dunlevy case, ${ }^{75}$ where no state court had the power to compel appearance by all claimants. When all parties have appeared in the state suit, either voluntarily or in response to valid service of process, the necessity for the invocation of the federal remedy disappears. ${ }^{76}$ The federal court can

Brillhart v. Excess Ins. Co. of America, 316 U.S. 491, 495 (1942).

${ }^{70}$ Bethlehem Steel Corp. v. Tishman Realty \& Constr. Co., 72 F.R.D. 33, 41 \& n.12 (S.D.N.Y, 1976) ("plaintiff makes no claim" that all issues not in state court, or state court unable to resolve them).

71 This will ordinarily be the same party opposing the motion to stay or dismiss.

${ }^{72}$ See, e.g., B.J. Van Ingen \& Co. v. Connolly, 225 F.2d 740, 745 (3d Cir. 1955) (state court judgment entered one day before federal interpleader filed, so dismissal proper).

${ }^{73}$ See, e.g., General Exporting Co. v. Star Transfer Line, 136 F.2d 329, 334 (6th Cir. 1943) (district court properly dismissed interpleader suit when state court had announced decision, although it had not entered decree, before federal suit was filed), cert. denied, 323 U.S. 724 (1944).

${ }^{24}$ Mutual Life Ins. Co. v. Egeline, 30 F. Supp. 738, 741 (N.D. Cal. 1939).

${ }^{78}$ New York Life Ins. Co. v. Dunlevy, 241 U.S. 518 (1916). See text and notes at notes 10-11 supra.

${ }^{76}$ Equitable Life Assurance Soc'y v. Cooper, 328 F. Supp. 1126, 1127 (W.D. Okla. 1971); 
require affidavits showing that service has been achieved on all parties; ${ }^{77}$ if one or more parties in the state suit are challenging personal service on them, and that challenge remains unresolved, dismissal has nevertheless been ordered on the basis that the state suit is in rem. ${ }^{78}$

The lower courts have disagreed on the propriety of a stay or dismissal when not all parties are before the state court. Some have refused to defer to the state suit without further inquiry; ${ }^{78}$ others have deferred on a showing that all necessary parties not yet present in the state suit can be brought into that proceeding. ${ }^{80}$ This latter approach is expressly approved in Brillhart, where the Court deemed it proper to consider not only whether all necessary parties had been joined but also whether such parties were amenable to process. ${ }^{81}$

Once it has been determined that all parties necessary for a just adjudication have been or can be joined in concurrent state proceedings, the federal court must ascertain whether any relevant issues are foreclosed by applicable procedural or substantive state law. Procedural rules are more likely to present obstacles, as not all states have imitated the liberality of the federal interpleader statute. It is possible, for instance, that the state does not allow interpleader by way of defense, counterclaim or cross-claim as does the federal statute, ${ }^{82}$ but only as an original bill in equity. It is also possible that state rules require the stakeholder to be completely disinterested; under the Federal Act the stakeholder is allowed to assert defenses as to one or more of the stakeholders. ${ }^{83}$ In either situation it should be fairly clear that the state proceedings are incapable of affording full relief, and a stay or dismissal would be

Mutual Life Ins. Co. v. Egeline, 30 F. Supp. 738, 741 (N.D. Cal. 1939).

${ }_{77}$ Mutual Life Ins. Co. v. Egeline, 30 F. Supp. 738, 740 (N.D. Cal. 1939).

${ }^{78}$ Zellen v. Second New Haven Bank, 454 F. Supp. 1359, 1362, 1366 (D. Conn. 1978).

79 E.g., Commonwealth Edison Co. v. Gulf Oil Corp., 400 F. Supp. 888, 889 (N.D. Ill. 1975), aff'd, 541 F.2d 1263 (7th Cir. 1976); Fidelity \& Deposit Co. v. A.S. Reid \& Co., 16 F.2d 502, 503 (E.D. Pa. 1926). Cf. Jefferson Std. Life Ins. Co. v. Smith, 161 F. Supp. 679, 680 (E.D.S.C. 1956) (mere assertion that a party not in the state suit could be impleaded held insufficient to justify abstention).

so Cf. Consolidation Coal Co. v. Bailey, 308 F. Supp. 1251, 1253 (N.D.W. Va. 1970) (employees could intervene in the state suit; if they did not, company could have them brought in as indispensable third parties); Agricultural Ins. Co. v. Lido of Worcester, Inc., 63 F. Supp. 799, 802 (D. Mass. 1945) (parties missing from the state suit "may be impleaded").

S1 See text at note 69 supra.

${ }^{82}$ FED. R. CIV. P. 22(1).

83 28 U.S.C. $\S 1335$ (a) (1976). 
improper. One court has held that the stakeholder was not adequately "protected" until a court of competent jurisdiction had issued a valid order discharging him from liability. ${ }^{84}$ In the case of a bill in the nature of interpleader, however, the stakeholder wishes to remain in court to assert defenses against one or more of the claimants, so such a holding requires too much.

\section{B. Balancing}

Once the threshold inquiry by the court has established the adequacy of the state remedy, the court may balance diverse factors to determine whether to accept interpleader jurisdiction.

1. Interpleader Jurisdiction Is Permissive. In order to make the balancing involved at all meaningful, it is first necessary to give content to the "virtually unflagging obligation" faced by the federal courts under the particular jurisdictional grant involved. Congress conceivably could confer jurisdiction on the federal courts for reasons or under circumstances that do not indicate a mandate, but rather a permissive grant. The argument is that, given the reasons for a particular grant of jurisdiction, as manifested in the legislative history, it should be possible to determine just how "unflagging" is the obligation facing the district court, once the jurisdiction has been properly invoked.

In contrast to the absolute right doctrine, which interprets all congressional grants of jurisdiction as mandatory, this analysis distinguishes among the various grants. Professor Chafee argued that, as with any equitable remedy, interpleader should not be granted when the parties have an adequate remedy at law. ${ }^{85}$ In conformity with this principle it has been held that interpleader under the Federal Act should be allowed only when it appears that the remedy is necessary, that is, when the petitioner has no adequate legal remedy. ${ }^{86}$

Brillhart v. Excess Insurance Co. of America, ${ }^{87}$ in which the Court affirmed dismissal of a suit asking declaratory relief, was a diversity case. While it has been noted ${ }^{88}$ that the Federal Declara-

84 Jefferson Std. Life Ins. Co. v. Smith, 161 F. Supp. 679, 680 (E.D.S.C. 1956).

${ }^{85}$ Chafee, Modernizing Interpleader, supra note 19, at 821. See also Klaber v. Maryland Cas. Co., 69 F.2d 934, 936 (8th Cir. 1934) ("The true origin of [interpleader] jurisdiction is that there is no remedy at law or that the legal remedy is inadequate").

${ }^{86}$ Preston Corp. v. Raese, 236 F. Supp. 135 (N.D.W. Va. 1964), aff'd, 377 F.2d 263 (4th Cir.), cert. denied, 389 U.S. 931 (1967).

316 U.S. 491 (1942).

Id. at 494 . 
tory Judgments Act is permissive in its terms, and the Interpleader Act is not, ${ }^{89}$ the analogy of that Act to the Interpleader Act is nevertheless compelling. Both interpleader and declaratory judgment are remedies; as the Court pointed out in Brillhart, if the controversy could be fully adjudicated in the pending state proceeding, federal declaratory relief would be unwarranted. ${ }^{90}$ The declaratory remedy was provided because a party could not be deemed to have an adequate remedy if required "to violate or purport to violate a statute in order to obtain a judicial determination of its meaning or validity."

Congress provided for relief by interpleader for similar reasons. In either situation, the party seeking invocation of the remedy is in an unconscionable position: the party faces either criminal sanctions or double liability, while it is incapable of securing prior and adequate determination of legal rights. Whatever the reasons underlying the grant of general diversity jurisdiction, federal interpleader was made available because a stakeholder had no adequate legal remedy when faced with conflicting claims asserted by parties not amenable to service of process in a single state jurisdiction. ${ }^{82}$ Professor Chafee argued that to interpret the grant of interpleader jurisdiction as permissive was in conformity with the purpose of the Federal Interpleader Act of 1936, ${ }^{\text {,3 }}$ which was "that the United States courts should be given power to settle all interpleader cases that cannot be handled by the state courts."94 Chafee also interpreted the act as intending to "leave the district courts free to use their discretionary powers to refuse relief and send the stakeholder to another forum, whenever the facts make such a course just and convenient."9s

A final reason for construing federal interpleader jurisdiction as permissive rather than mandatory is highlighted by Colorado

89 Compare 28 U.S.C. § 2201 (1976) ("any court of the United States . . . may declare the rights . . . of any interested party" (emphasis added)) with 28 U.S.C. $\S 1335$ (a) (1976) ("The District Courts shall have original jurisdiction of any civil action of interpleader" (emphasis added)).

so Brillhart v. Excess Ins. Co. of America, 316 U.S. 491, 495 (1942).

S. Rep. No. 1005, 73d Cong., 2d Sess. 203 (1934).

"2 See, e.g., S. REP. No. 660, 64th Cong., 1st Sess. 2 (1916); S. REP. No. 558, 74th Cong., 1st Sess. 2-4 (1936).

os Act of June 20, 1936, ch. 13, 49 Stat. 1096 (current version at 28 U.S.C. $§ \S 1335$, 1397, 2361 (1976)).

* Chafee, The Federal Interpleader Act of 1936 (pt. 1), supra note 19, at 975 (emphasis added).

${ }^{\circ s}$ Id. at 985. 
River. In that case the Court relied heavily on the clear federal policy of avoiding piecemeal adjudication of water rights evinced by the McCarran amendment, adding that "[ $t]$ his policy is akin to that underlying the rule requiring that jurisdiction be yielded to the court first acquiring control of property, for the concern in such instances is with avoiding the generation of additional litigation through permitting inconsistent dispositions of property." However appropriate the analogy to the in rem rule may have been with respect to the McCarran amendment, ${ }^{97}$ it is particularly compelling with respect to interpleader. The avoidance of piecemeal adjudication, with the consequent possibility of multiple or inconsistent liabilities, is the primary goal of the device; indeed, the history of interpleader as an equitable remedy demonstrates beyond question that its evolution was a response to precisely those considerations. ${ }^{98}$ These considerations leave no doubt that federal jurisdiction under the interpleader statute is permissive to the extent that the rationale for invoking it is absent in any particular case.

2. Convenience to the Courts and to the Parties. In order to complete the balancing process, considerations of "wise judicial administration" will dictate whether deference to state proceedings is appropriate. The factors that a court should consider can be grouped into two categories: those relevant to the conservation of judicial resources, and those concerning convenience and fairness to litigants. ${ }^{98}$

a. Judicial economy. Few would deny that it is in the public interest to avoid the waste of judicial resources. ${ }^{100}$ Especially in light of the constantly expanding workload of the federal courts, avoidance of unnecessary duplication of judicial effort should have a high priority. ${ }^{101}$ In other contexts, the Supreme Court has held that in its sound discretion a court of equity may refuse to protect private rights when the exercise of its jurisdiction would be preju-

- Colorado River Water Conservation Dist. v. United States, 424 U.S. 800, 819 (1976).

97 The dissenters thought the analogy inapposite. Id. at 822 (Stewart, J., dissenting).

98 See text and notes at notes 8-9 supra.

2* Aetna State Bank v. Altheimer, 430 F.2d 750, 755 (7th Cir. 1970); Mottolese v. Kaufman, 176 F.2d 301, 303 (2d Cir. 1949) (L. Hand, C.J.). Cf. Landis v. North Am. Co., 299 U.S. 248,254 (1936) (same grounds govern stays in deference to parallel proceedings in another district court).

${ }^{100}$ Comment, Colorado River Water Conservation District v. United States: An Increased Role for State Courts in the Adjudication of Federal Reserved Water Rights, 1977 UTAH L. REV. 315, 328.

101 See Aetna State Bank v. Altheimer, 430 F.2d 750, 755-56 (7th Cir. 1970); authorities cited note 7 supra. 
dicial to the public interest. ${ }^{102}$ There is a clear public interest in the availability of a system of courts not overcrowded by the presence of numerous duplicative suits. ${ }^{103}$ Thus, while docket congestion does not, standing alone, justify deference to parallel state proceedings, the reduction in case load is an ancillary benefit to be derived from an otherwise justified stay or dismissal. ${ }^{104}$

Mere priority in time of the state suit is not a sufficiently precise substitute for determining whether deference will result in a gain in judicial economy; ${ }^{105}$ the state court docket might be more or less congested than the federal. What is needed, rather, is some rough estimate of the relative progress of the parallel suits, as well as an assessment of the relative likelihood of prompt disposition in the two forums. ${ }^{108}$ As Professor Currie has succinctly noted, "[a] race to the courthouse is arbitrary and unseemly, but it is no more so than the present race to judgment in two suits filed one after the other, and it involves a good deal less waste."10z

An important benefit of deference to concurrent proceedings is the avoidance of delay. While delay is one of the horrors involved in preservation of the right to return to federal court in the first two categories of abstention, ${ }^{108}$ the avoidance of delay is one of the primary considerations in the determination of whether to stay or dismiss for reasons of wise judicial administration. ${ }^{109}$

${ }^{102}$ E.g., Pennsylvania v. Williams, 294 U.S. 176, 185 (1935); United States ex rel. Greathouse v. Dern, 289 U.S. 352, 360 (1933).

${ }^{103}$ E.g., Universal Gypsum, Inc. v. American Cyanamid Co., 390 F. Supp. 824, 828-29 (S.D.N.Y. 1975). "Litigants who have no other forum available to them should not be asked to stand aside while we engage in diversity litigation which is duplicative of that pending in a state court of competent jurisdiction." Id. at 830 .

${ }_{104}$ See Weiner v. Shearson, Hammill \& Co., 521 F.2d 817, 820 (9th Cir. 1975); Atchison v. Nelson, 460 F. Supp. 1102, 1109 (D. Wyo. 1978).

${ }^{105}$ E.g., Zellen v. Second New Haven Bank, 454 F. Supp. 1359 (D. Conn. 1978); Chintala v. Diamond Reo Trucks, Inc., 393 F. Supp. 1392, 1394 (E.D. Pa. 1975).

${ }_{10}$ Cf. Bethlehem Steel Corp. v. Tishman Realty \& Constr. Co., 72 F.R.D. 33, 41 n.12 (S.D.N.Y. 1976) (likelihood of prompt disposition in alternative forum a factor); Bandag, Inc. v. Saliga, 314 F. Supp. 432, 435 (D. Md. 1970) (state court trial calendar permits prompt trial, which is one factor in determining that stay is nonprejudicial).

${ }^{107}$ Currie, The Federal Courts and the American Law Institute (pt. 2), 36 U. CHI. L. Rev. 268, 335 (1969). See also Weiner v. Shearson, Hammill \& Co., 521 F.2d 817, 820 (9th Cir. 1975) (dual litigation might involve courts in an unseemly race to judgment).

${ }^{108}$ See, e.g., England v. Louisiana State Bd. of Medical Examiners, 375 U.S. 411, 419 (1964); id. at 425-26 (Douglas, J., concurring); Currie, supra note 107, at 317.

${ }^{109}$ Cf. Augustin v. Mughal, 521 F.2d 1215, 1217 (8th Cir. 1975) (no showing that abstention would cause delay cited as one of the reasons for holding suit was improperly dismissed). 
The policies underlying the removal statute ${ }^{110}$ provide further support for dismissals for reasons of judicial economy. In any case brought in state court that is within the original jurisdiction of the federal courts, the defendant(s) may remove to the federal court.111 If the defendant could have removed but did not, and later attempts to circumvent the time limitation on the availability of removal ${ }^{112}$ by filing an original bill in the federal court, sound policy considerations support disallowance of the duplicative suit; Congress has determined that state courts are an adequate forum for suits not within the removal statute. ${ }^{113}$ Some courts have deemed this an additional factor in determining the propriety of a stay. ${ }^{114}$

Finally, all other things being equal, the case for abstention is particularly strong when applicable state law is unclear. ${ }^{115}$ The suggestion is implicit in Brillhart that the more appropriate forum is that whose law will be applied. ${ }^{116}$ Federal judges occasionally have been moved to remark upon the frustration involved in "predicting" state law, only to be proven "wrong" by a subsequent ruling of the highest state court. ${ }^{112}$ Thus, if other positive reasons justifying abstention appear, the lack of clarity of the applicable state law may appropriately serve to tip the scales affirmatively in favor of abstention.

b. Convenience and fairness to litigants. It has been common for the lower federal courts to consider the burden placed on litigants who have to prosecute or defend more than one lawsuit in courts of concurrent jurisdiction. ${ }^{118}$ There is ample precedential as

11028 U.S.C. $\S \S 1441-1451$ (1976).

${ }^{111} I d . \S 1441(\mathrm{a})$. This procedure is followed unless the case is based solely on diversity of citizenship, and one or more of the defendants is a citizen of the state where the action is brought. Id. \& 1441(b).

112 The defendant must seek removal within 30 days of his receipt of a copy of the initial pleading. Id. $\S 1446$ (b).

113 Examples are federal defenses and local defendants in diversity cases. See Comment, supra note 26 , at 666-71.

${ }^{114}$ E.g., Calvert Fire Ins. Co. v. American Mut. Reins. Co., 459 F. Supp. 859, 862 n.3, 864 (N.D. Ill. 1978), aff'd, 600 F.2d 1228 (7th Cir. 1979).

${ }_{115}$ See Clarkson Co. v. Shaheen, 544 F.2d 624, 629 (2d Cir. 1976).

116 Brillhart v. Excess Ins. Co. of America, 316 U.S. 491, 495 (1942). See Universal Gypsum, Inc. v. American Cyanamid Co., 390 F. Supp. 824, 827 (S.D.N.Y. 1975) ("Their resolution will be controlled by the applicable precedents of New York contract law whether the trial is had in this courthouse or across the street"); D. CuRRIE, supra note 5, at 681.

${ }^{117}$ E.g., United Servs. Life Ins. Co. v. Delaney, 328 F.2d 483, 486 (5th Cir.) (Brown, J., concurring), cert. denied, 377 U.S. 935 (1964).

${ }_{118}$ See, e.g., Bethlehem Steel Corp. v. Tishman Realty \& Constr. Co., 72 F.R.D. 33, 41 \& n.12 (S.D.N.Y. 1976). 
well as statutory ${ }^{119}$ support for the consideration of this factor, in situations involving the doctrines of pendent jurisdiction ${ }^{120}$ and forum non conveniens. ${ }^{121}$ Additional support is derived from the argument of Professor Chafee that the Interpleader Act allows the district court to dismiss the suit and direct the parties to begin anew elsewhere, if considerations of justice and convenience so require. ${ }^{122}$ What is important here is the relative convenience of the alternative forum, as measured by ease of access for geographically diverse parties and witnesses.

Another consideration involves the relative weight to be given to the forum choice of the various parties. With strict interpleader it is particularly appropriate to vindicate the forum choice of a claimant rather than that of the stakeholder, because the latter will be discharged upon establishing entitlement to the remedy and payment of the fund into court. The venue provisions of the Federal Act require suit to be brought in a district in which one or more of the claimants reside. ${ }^{123}$ This supports the inference that, while federal interpleader was necessary to alleviate the Dunlevy problem, an insurer, for example, would not be allowed to use the newly available forum to the disadvantage of the claimants. It is a short step from that proposition to the conclusion that, if a claimant has chosen a state forum prior to institution of the federal interpleader suit, that choice should be vindicated absent any necessity for invocation of the federal jurisdiction.

Courts have refused to allow abuse of the legal system when it appears that the federal suit is a purely reactive defensive maneuver, or a vexatious suit. ${ }^{124}$ In either case the courts should not lend their sanction to forum shopping, wasteful maneuvering, delaying tactics, or coerced settlements derived from the dual burden placed on litigants by duplicative litigation. Public policy presents strong support for furnishing district judges with the means by which to prevent such improper use of the federal courts. ${ }^{125}$

119 28 U.S.C. $\$ 1404(a)$ (1976) (change of name for the convenience of parties and witnesses).

${ }^{130}$ See UMW v. Gibbs, 383 U.S. 715, 726 (1966).

121 See Gulf Oil Corp. v. Gilbert, 330 U.S. 501, 508-09 (1947).

123 See Chafee, The Federal Interpleader Act of 1936 (pt. 1), supra note 19, at 974-75.

${ }^{123} 28$ U.S.C. $\S 1397$ (1976). Cf. Chintala v. Diamond Reo Trucks, Inc., 393 F. Supp. 1392 (E.D. Pa. 1975) (initial choice of forum alone not determinative).

${ }^{124}$ E.g., Calvert Fire Ins. Co. v. American Mut. Reins. Co., 459 F. Supp. 859, 861-62 (N.D. Ill. 1978), aff'd, 600 F.2d 1228, 1236 (7th Cir. 1979).

${ }^{128}$ See generally Currie, supra note 107, at 335; Kurland, Toward a Cooperative Judicial Federalism: The Federal Court Abstention Doctrine, 24 F.R.D. 481, 491 (1959). Both 
It should be noted that considerations of convenience to litigants will rarely, if ever, be determinative of the decision of the federal court whether to stay or proceed, if the balancing progresses in the proper order. Assuming that the threshold requirement of adequate state proceedings is met, the court first should determine which suit is the more economical in terms of judicial economy. If the state suit is found to allow the more expeditious disposition of the litigation, the federal court will stay its hand; if the federal suit is the more economical, the district court is expressly authorized by the Interpleader Act to enjoin the litigants from proceeding further in the state suit. ${ }^{126}$ In either case, only one suit will go forward, thus ensuring that, whichever suit proceeds to judgment, the parties are freed from the burdens inherent in prosecuting or defending more than one suit over the same controversy.

A brief comment on the practicability of the balancing test outlined above is in order. Unlike so many areas where balancing is required, the nature and content of this test allow for both precision and predictability. The court is required to balance factors of judicial economy and convenience to litigants only after it has been shown that either of the parallel suits is capable of protecting the interests of all the parties. It is then a relatively simple matter to determine which can do so more economically; the other suit then will cease.

Two further matters deserve mention. First, once the determination has been made that deference to a parallel state suit is warranted, the federal court must decide whether to retain jurisdiction or to dismiss the interpleader suit outright. ${ }^{127}$ The advantage of a stay is obvious: since jurisdiction over the federal interpleader is thereby retained, the stay can be modified or discontinued and the state interpleader enjoined, should it develop that the state proceeding is in fact inadequate to protect all parties, ${ }^{128}$ or that, for whatever reason, the federal suit can be disposed of more expedi-

Professors Currie and Kurland argue that the Judicial Code should be amended to provide for stays in this situation.

12828 U.S.C. $\$ 2361$ (1976).

${ }^{127}$ Some courts, rather than staying or dismissing the duplicative action, have "abated" it. E.g., Baer v. Fahnestock \& Co., 565 F.2d 261, 263 (3d Cir. 1977); Weiner v. Shearson, Hammill \& Co., 521 F.2d 817, 820-21 (9th Cir. 1975). Because the Federal Rules of Civil Procedure do not provide for abatement, this discussion concerns only the propriety of stays as opposed to dismissals.

${ }^{128}$ See Calvert Fire Ins. Co. v. American Mut. Reins. Co., 459 F. Supp. 859, 861 (N.D. Ill. 1978), aff'd, 600 F.2d 1228 (7th Cir. 1979). 
tiously. ${ }^{129}$ The parties remain free to petition the court for modification of the stay order in the event that circumstances change. ${ }^{130}$

Second, a stay order ordinarily is not appealable, because it is not a final judgment. ${ }^{131}$ To treat a stay in this context as an appealable final judgment would be unjustified both in light of the policy of the final judgment rule, and because the parties remain free to petition for discontinuance of the stay order. ${ }^{132}$ It would effectively negate any gain in judicial economy if the parties simply moved up to a court of appeals, while continuing to litigate the state interpleader.

\section{ConcLusion}

The Federal Interpleader Act was passed to aid the stakeholder who, when faced with diverse claimants to a single fund, could not force all parties to join in a single suit. It is perfectly consistent with this congressional intent to restrict the availability of the federal remedy to situations in which that inability of the stakeholder is not remedied by the presence of all necessary parties in a single suit pending in a state court of competent jurisdiction. ${ }^{13 s}$ This conclusion leads to substantial ancillary benefits: avoidance of federal-state friction caused by unnecessary interference by injunction with the orderly processes of state courts, freedom of litigants from the burdens of duplicative litigation, relief from overcrowded dockets, and more efficient use of scarce judicial resources.

Mark W. Smith

139 See, e.g., Scott v. Germano, 381 U.S. 407, 409-10 (1965) (per curiam); Langnes v. Green, 282 U.S. 531, 541-42 (1931).

130 Applegate v. Devitt, 509 F.2d 106, 109 \& n.2 (8th Cir. 1975).

15128 U.S.C. § 1291 (1976).

132 Will v. Calvert Fire Ins. Co., 437 U.S. 655,665 (1978).

1ss See Zellen v. Second New Haven Bank, 454 F. Supp. 1359, 1365-66 (D. Conn. 1978): "The state court interpleader currently pending is in a position to comprehensively dispose of all the potential litigation ... while facilitating the most efficient allocation of judicial resources and relieving the [stakeholder] of the unfairness of litigating the same action in two different courts (an abuse of the judicial system interpleader suits are intended to forestall)." 